\title{
VICTIM INJURY AND DEATH IN URBAN ROBBERY: A CHICAGO STUDY
}

\author{
FRANKLIN E. ZIMRING and JAMES ZUEHL*
}

$\mathbf{R}$ OBBERY, the taking of property by force or threat of force, is a major problem in its own right and a central issue in the analysis of violent crime in America. Robbery is a property crime, unlike theft and burglary, that frequently threatens the physical security of its victim. ${ }^{1}$ Robbery is a crime of violence that strikes many more victims than rape ${ }^{2}$ and reaches across boundaries of social distance far more often than aggravated assault. ${ }^{3}$ Robbery is the stranger-to-stranger crime that most frequently results in victim death and injury in the United States. ${ }^{4}$

This paper reports the first systematic comparison of noninjury, injury, and fatal robberies in a big city setting. The first section of this report addresses our empirical findings, including estimates of the volume of robbery killing in Chicago, an analysis of patterns of robbery killing, an examination of patterns of robberies that cause injury, and a preliminary

* Zimring is Professor of Law and Director of the Earl Warren Legal Institute, University of California, Berkeley. Zuehl is Research Fellow, Center for Studies in Criminal Justice, University of Chicago Law School, and Instructor, Illinois Institute of Technology, Chicago-Kent Law School. The research reported in these pages was supported by grant NIJ 83-IJ-CX-0012, National Institute of Justice, by the University of Chicago Law School and the Program in Criminal Justice of the Earl Warren Legal Institute at the University of California, Berkeley. We gratefully acknowledge the patience and cooperation of the Chicago Police Department in facilitating this research, the comments of Lois Mock, Philip Cook, Jerome Skolnick, Richard Block, Carolyn R. Block, and Stephen Sugarman on an earlier draft of this article, and the research assistance of Todd Postel, Anura Goonasekera, and Llewellyn Cornelius.

${ }^{1}$ Franklin Zimring, Determinants of the Death Rate from Robbery: A Detroit Time Study, 6 J. Legal Stud. 317 (1977).

2 The ratio is greater than six to one. See Federal Bureau of Investigation, Crime in the United States, 1983 (1984), at 13, 16.

3 See U.S. Department of Justice, Bureau of Justice Statistics, Criminal Victimization in the United States, 1979 (1981), at 45, table 35.

${ }^{4}$ The FBI estimates about 60 percent of all killings during other forcible felonies stem from robbery. Federal Bureau of Investigation, supra note 2, at 11.

[Journal of Legal Studies, vol. XV (January 1986)]

(C) 1986 by The University of Chicago. All rights reserved. $0047-2530 / 86 / 1501-0010 \$ 01.50$ 
look at rates of clearance by the police of various categories of robbery. A second section addresses some implications of this study for criminological theory and criminal law.

The study collected data on robbery experience in the city of Chicago over a twelve-month period. Our central interest is those factors and conditions in robbery events that cause victim injury and death. Chicago is a large city with a large volume of robbery, robbery resulting in victim injury, and robbery killing. ${ }^{5}$ The study period extended from October 1 , 1982, through September 30, 1983. For that period we gathered data on all killings classified by the police as robbery related (a total of ninety-five), on the 142 killings for which no motive was assigned by the police, on a sample of 346 robberies resulting in victim injury, ${ }^{6}$ and on a sample of 360 nonlethal robberies of all kinds that were reported to and recorded by the Chicago police. ${ }^{7}$

The data in this study were collected prospectively-or, more accurately, almost prospectively-rather than as a historical record of past events. Each month, the fatalities and sample of nonfatal cases were referred to us within a short period after the police report. In many of the death cases, we were thus able to interview police while an investigation was still in progress or shortly after it concluded. We were often able to correct misstatements or premature inferences in the paper record of the case and to benefit from the developing insights of the investigation process.

\section{The Study}

Our analysis compares three different types of robbery events: those that result in death, those that cause injury, and a representative sample of all nonfatal robberies reported to the police. The first section of this paper reports on our efforts to estimate the frequency of robbery killings using homicide records of the Chicago police. The next section compares the profile of fatal robberies with a sample of nonfatal robberies obtained from offense reports submitted to the Detective Division of the Chicago Police Department. Finally, we introduce a special sample of offense

\footnotetext{
${ }^{5}$ Population estimates for 1983 put the city population at just under $3,000,000$. Policereported robbery volume was 23,471 , and reported robbery killings totaled 115 . See note 8 infra.

6 The sample was constructed from a screening and referral of the first thirty reports of robbery to the Detective Division where a notation was present that hospital assistance was required.

${ }^{7}$ This sample consisted of the first thirty robbery offense reports reaching the Detective Division each month.
} 
reports indicative of serious injury that are contrasted with robbery killings and representative nonfatal robbery events.

\section{A. Estimating the Volume of Robbery Killing}

A first approximation of Chicago's robbery killing rate can be derived from police statistics. In 1983, Chicago police reported that a total of 115 criminal homicides were classified as robbery related-16 percent of that year's homicides, and a rate of 3.8 per 100,000 population. When robbery killings are compared with the volume of officially reported robberies $(23,471$ in 1983), the police numbers produce an official death rate of 4.9 per thousand robberies. ${ }^{8}$

There is reason to believe that estimates of robbery killing based on such aggregate statistics are inaccurate. One problem, largely beyond the scope of this study, is that only a proportion of all robberies occurring in Chicago are reported to the police by victims. A second problem is that many of the robberies reported to the police by victims are not so classified by the police in official statistics.

Underreporting, both to and by the police, reduces the number of robberies in the denominator of statistics used to derive an official death rate and thus results in a higher death risk estimate for individual robbery events than actually occurs. ${ }^{9}$ Underestimating the universe of robbery events, however, does not undermine estimates of the number of robbery killings or the proportion of criminal homicides attributable to robbery.

The notion of an overall statistic expressing a death risk for robbery is also misleading because different types of robbery carry different risks of victim fatality. ${ }^{10}$ Aggregating all types of robbery killing and dividing this figure into a parallel conglomeration of diverse robberies produces a total

${ }^{8}$ These statistics are derived from reports published by the Chicago Police Department: the robbery-homicide total is reported in Murder Analysis 1983, and the robbery total is reported in Statistical Summary 1983. The total number of robberies officially reported by the police $(23,471)$ represents the number of incidents originally identified by the police as robberies $(24,940)$ minus those later categorized as unfounded $(1,469)$. The number of unfounded robberies is small in 1983 compared to recent years in part because the police department changed its practice in response to media charges, made late in 1982, that the department was systematically undercounting crimes by dismissing incident reports as unfounded. A departmental audit based on a sample of cases from 1982 indicated that less than 20 percent of the unfounded cases were properly classified. The figures for 1983 appear to be relatively free of this problem.

9 Both sources of underreporting are examined in detail in Richard Block \& Carolyn $\mathbf{R}$. Block, Decisions and Data: The Transformation of Robbery Incidents into Official Robbery Statistics, 71 J. Crim. L. \& Criminology 622 (1980).

10 See Table 2 and the accompanying discussion. 
death risk statistic only useful for gross comparisons, even if official statistics on robbery killings were accurate.

Unfortunately, official estimates of robbery killings are far from perfect, and the margin of error associated with these statistics is a central concern of this study. Violent killings stemming from robbery do not result in the kind of underreporting to and by the police associated with nonfatal robbery events. Fatal stabbings and shootings inevitably come to the attention of the police and almost always are reported as criminal homicides. Frequently, however, the events leading to a violent killing are not clear to the investigating officers, so that the motive for a violent death cannot be confidently determined. To the extent that robbery killings are not classified accurately by motive, the risk of a robbery event leading to death will be understated by official statistics and the volume of robbery killings will be undercounted.

The problem of undercounting robbery killings because of difficulty in establishing homicide motives has become particularly acute over the past two decades as robbery homicide and the number and proportion of all homicides of undetermined motive have increased. In 1965, for example, only thirty-one of Chicago's 395 homicides were classified as robbery related by the police. An additional nine killings, fewer than 3 percent of the total, were classified as motive undetermined. ${ }^{11}$ By the 1970 s, however, both official robbery killings and the number of killings of undetermined motives increased substantially. ${ }^{12}$ Between 1965 and 1983 the number of robbery killings in Chicago increased more than threefold from thirty-one to 115 . The number of killings classified as motive undetermined increased thirteenfold from nine in 1965 to 117 in 1983. When the number of unclassified killings is roughly equal to the total volume of officially reported robbery homicides, the margin of error in estimating the volume of robbery deaths is unacceptably high.

One approach would allocate killings with unknown motives among various motive categories in the same proportion as killings for which motive has been determined. For example, there were 612 homicides in 1982 in which the police were confident of the motive of killing. Since 19 percent of these cases were classified as robbery deaths, this method would allocate 19 percent of the motive-undetermined killings $(.19 \times 117$ $=22$ ) to the robbery category, thereby increasing the number of estimated 1983 robbery homicides from 115 to 137.

If we knew nothing of patterns of homicide, this "naive" accounting scheme might be an acceptable method of dealing with the uncertainties

"Chicago Police Dep't, Murder Analysis 1965. See also Appendix Table A1.

12 See Appendix Table Al. 
generated by unclassified cases. However, since it is known that the bulk of all cases of homicide in Chicago involve a prior relationship between victim and offender, ${ }^{13}$ it is unwise to suppose that an equal proportion of different types of homicide end up in the motive-undetermined category. Domestic and romantic homicides, for example, are about as frequent as classified robbery killings in Chicago homicide statistics. ${ }^{14}$ The close relationship between victim and offender and the usually obvious motive make it unlikely that many domestic cases will come to the attention of the authorities without providing a sufficient factual basis for a police classification of motive.

Robbery killings and unknown-motive killings, by contrast, share a number of characteristics that make police fact-finding difficult and motives hard to classify. A substantial percentage of both kinds of killing involves a victim and offender with no known prior acquaintance, many killings lack third party witnesses, and the motive for the violence must frequently be inferred from sparse circumstantial details. ${ }^{15}$ It seems likely therefore that a larger proportion of actual robbery killings arise from cases where the motive is undetermined than any naive projection would estimate.

In order to gain a more sensitive estimate of how many motiveundetermined killings are likely to have resulted from robbery motive, we resorted to a reanalysis of the investigative records of reported robbery killings and of those for which motive was undetermined. ${ }^{16}$ All officially

13 Richard Block \& Franklin E. Zimring, Homicide in Chicago, 1965-1970, 10 J. Research in Crime and Delinquency 3 (1973); Richard Block, Homicide in Chicago: A Nine-Year Study (1965-1973), $66 \mathrm{~J}$. Crim. L. and Criminology 496 (1976); Richard Block, Violent Crime 40 (1977); Chicago Police Dep't, Murder Analysis (1965-82).

14 One hundred and four of the 668 murders ( 15 percent) in Chicago in 1982 were classified by police as involving domestic or romantic relationships. Chicago Police Dep't, Murder Analysis 1982, at 15 . This total excludes some triangle killings where the victim is killed by a rival.

15 In 57 percent of the unknown-motive killings the victim and offender were known to have been strangers or the absence of information created the possibility that they were not acquainted. In about $\mathbf{4 0}$ percent of the unknown-motive killings the police were not able to identify any witnesses who were nearby when the incident occurred. In almost half the unknown-motive cases it was not possible for the police to tell with certainty whether or not any of the victim's valuables were taken. Three months after the close of the data collection period (October 1982-September 1983), less than a quarter of the unknown-motive killings had been cleared.

${ }^{16}$ Cases were reanalyzed by Detective Ed Carter of the Chicago Police Department's Crime Analysis Unit. Detective Carter was asked to perform the reanalysis because of his extensive experience in robbery investigations and his lack of involvement in the original classification of homicide cases. His generous assistance is gratefully acknowledged. Detective Carter reanalyzed 146 cases (ninety-nine cases originally classified as motive undetermined and forty-seven as robbery homicide). The robbery homicide cases were included 
classified motive-undetermined cases and a large sample of classified robbery killings that occurred during our study period were submitted to a Chicago police detective for his assessment of the probability that the killing resulted from a robbery. The label attached to the official police investigation was not provided to our informant, but the file was not purged of descriptive materials that might alert the rating officer to the suspicions of the investigating field personnel. The result of this exercise is reported in Figure $1 .^{17}$

The first lesson of Figure 1 is that the police are apparently conservative in describing killings as robbery related. The overwhelming majority of killings described as robbery related in the initial investigation were so classified by independent rerating. Because the rerating was based on a paper record generated by initial investigators, the process was probably biased by the views of the investigative detectives as reflected in the file. But the contrast between the rerating of killings that were classified as robberies and those that were classified motive undetermined still supports an inference of conservative robbery classification.

Figure 1 also shows that a sizable proportion of killings classified by police as motive undetermined may have involved robbery. Fifteen percent of the 143 motive undetermined deaths were rerated as probable or very possible robbery killings, and an additional 26 percent were listed as possible robbery outcomes. Thus, in almost four out of ten motiveundetermined killings, robbery offered a plausible explanation for the events as police understand them.

both to help mask from Detective Carter the original classification of the cases and to provide a check on the way these cases were originally classified. The reanalysis took place in the following way. For each case the detective was given a file containing the reports on which the original classification was based but devoid of any explicit indication what the original classification was. The detective was asked for each case to respond to the two following questions using the categories given: (1) What is the likelihood that a robbery or attempted robbery was involved in the homicide incident? (a) Probable. Substantial indications of a robbery are present, and they outweigh any contraindications. (b) Strong possibility. Substantial indications of a robbery are present, but they are balanced by contraindications. $(c)$ Moderate possibility. Indications of a robbery are weak, but there are no strong contraindications. $(d)$ Unlikely. Indications of a robbery are weak or absent, and there are strong contraindications. (2) If a robbery or attempt is likely to have taken place (that is, if the incident was rated $a-c$ above), choose the possibility below that best describes the relationship of the robbery or attempt to the killing. $(a)$ Robbery was the primary motive for the incident leading to the death. (b) Robbery was a consequence of but not the primary motive for the incident leading to death. (c) Not enough is known about the incident to make a reasonable choice.

17 The percentages reported in this figure represent the proportion of victims, rather than incidents, which was assigned to each probability level. In a few robberies more than one victim was killed. To make fatal and nonfatal robberies comparable, subsequent analyses use a single robbery event as a unit of analysis, rather than each death. 
INITIAL RATING
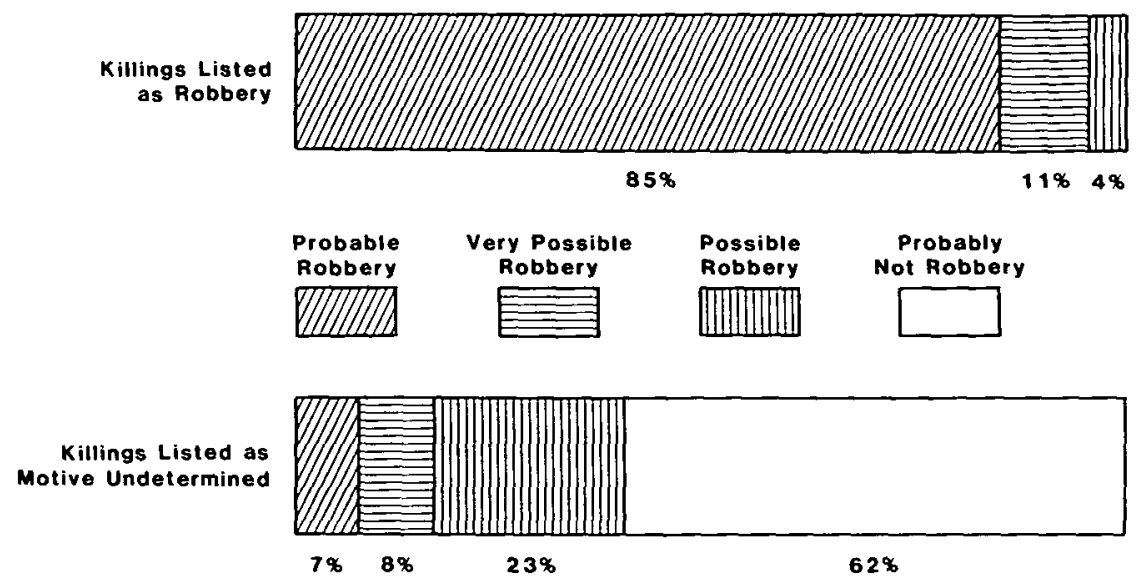

FIGURE 1.-Independent rating of robbery and motive-undetermined killings

The tendency to find more robberies in rerating may also be enhanced by the rerating officer's knowledge that the research process he was assisting was a study of robbery. The context of the study creates an atmosphere for decision that is perhaps more conscious of the possibility of robbery involvement than the ordinary police task of classifying homicides by selecting from a number of motive rubrics. Further, this "robbery consciousness" might have been enhanced by the fact that the rerating officer specializes in robbery investigation.

The consequences for the death rate statistic of adding in rerated cases are estimated in Table 1.

The number of criminal homicides associated with robbery ranges from under 100 (if only the highest robbery-probability category is counted) to 159 (including all possible robbery cases). The corresponding estimate of death risk, in each case based on officially classified robberies, ranges from less than five per thousand to almost seven per thousand. We think that dealing explicitly with the uncertainty of this range of estimates is more appropriate than attempting to put a finer point on matters by selecting an arbitrary cutoff point in the rerating process or using any other single estimation technique.

\section{B. Patterns of Robbery Killing}

One consequence of using a range of plausible estimates is the need to use alternative formulations when discussing patterns of robbery killing or estimating risks associated with different types of robbery events. At 
TABLE 1

Volume of Robbery Killings and Rate per Thousand Reported 1983 Robberies, Sample Year Data

\begin{tabular}{lcc}
\hline \hline & Number & $\begin{array}{c}\text { Rate Per } \\
\text { Thousand Robberies }\end{array}$ \\
\hline Officially classified robberies & 115 & 4.9 \\
Add probable robbery killings & 123 & 5.2 \\
Add very possible robbery killings & 132 & 5.6 \\
Add possible robbery killings & 159 & 6.8 \\
\hline
\end{tabular}

this early stage of research, we consider it advisable to institutionalize the margin of error inherent in the enterprise rather than settle on a single estimate that imposes artificial precision in subsequent analyses.

The uncertain boundary between robbery homicide and other apparently similar killings complicates attempts to analyze patterns of robbery killing. Table 2 provides an introduction to the complex nature of robbery killing patterns, comparing officially classified robbery killings during the study period with a sample of 360 nonfatal robberies reported to and by the Chicago police during the same twelve months. The contrast between robberies and robbery killings is striking. Just over half the officially reported robberies occur in street locations, and an additional 10 percent take place in commercial premises. This finding is consistent with the usual public perception of robbery locations. Only one in twelve of the sample of robbery events occurs in a place of residence. Robbery killings are another matter: just under 20 percent occur on the street, and the total volume of killings taking place in street and commercial locations (35

TABLE 2

Percentage Distribution of Robbery Killings and Robberies by Location, Chicago, 1982-83

\begin{tabular}{lcr}
\hline & Robbery Killings & Robberies \\
\hline Street & 19 & 51 \\
Commercial establishment & 16 & 10 \\
Residence & 36 & 8 \\
Other location* & 29 & 30 \\
$\quad$ Total & 100 & 100 \\
$N$ & 94 & 360 \\
\cline { 2 - 3 }$N$
\end{tabular}

Note. - Totals may not equal 100 due to rounding.

* Includes hallways, lobbies, and elevators of apartment buildings: gangways: yards: motor vehicles, including taxis and buses; and institutional settings such as churches or schools. 
TABLE 3

Percentage Distribution of Robbery Killings and Robberies by Police Classified Victim-OfFender Relationship, Chicago, 1982-83

\begin{tabular}{lcr}
\hline & Robbery Killings & Robberies \\
\hline Victim and offender acquainted & 21 & 6 \\
Victim might recognize offender & 2 & 4 \\
Strangers & 53 & 87 \\
Relationship unknown & 24 & 3 \\
Total & 100 & 100 \\
$N$ & 95 & 360 \\
\hline
\end{tabular}

percent) is about equal to the 36 percent of all officially reported robbery killings reported in residential settings.

A similar pattern emerges when the relationship between victim and offender is compared in robbery killings and robberies, the task of Table 3. A majority of robbery killings and of nonlethal robberies conform to the popular perception of robbery as a stranger crime. But more than one out of five robbery killings involve a prior relationship. In addition, no confident judgment could be made about victim-offender relationship in another 24 percent of the robbery killing cases. Thus the police are confident that victim and offender are strangers in just under nine out of ten officially classified robbery cases but in only about half of classified robbery killings.

Two preliminary points merit mention before more detailed analysis of patterns of robbery killing can proceed. First, the divergence of patterns of robbery killing from those of robbery, noted in Tables 2 and 3, is the most conservative estimate available on this data, as the tables deal only with officially classified robbery killings. Adding initially unclassified cases that were regarded as probable or possible robberies in the rerating exercise does not appreciably modify the contrast between patterns of reported robbery and robbery killing. ${ }^{18}$

Second, the sharp contrast between patterns of lethal and nonlethal robbery events is arguably attributable to the differential dangerousness of various types of robbery. On this view, the fact that residential robberies account for 36 percent of all deaths but only 8 percent of nonlethal robberies is testament to the greater dangerousness of residential robbery. Attributing all noted differences in death to dangerousness would

18 See, for example, Appendix Table A2. 
produce a provisional estimate that residential robbery is twelve times as dangerous as street robbery. ${ }^{19}$

An alternative interpretation would stress differences in reporting to and by the police as the major explanation of the sharp divergence of the patterns. A proponent of this view would stress the selective nature of victim reporting and police classification that feeds into the construction of patterns of officially noted nonlethal robbery. That only one out of ten nonlethal robberies involves a victim who might know his offender results from (1) victims' being less likely to report potential robberies to the police if they know the offender ${ }^{20}$ and (2) the natural tendency for police to classify violent conflicts among acquaintances as something other than robbery when victims do complain.

Our own view is that both the dangerousness and reporting hypotheses are partially correct. This in turn complicates the task of appropriately analyzing the differences officially noted.

The drug-related robbery killing illustrates the problem of differentiating between dangerousness and reporting explanations. Approximately one in six officially classified robbery killings involves strong circumstantial indications that the lethal event was drug connected, either because the victim was known as a drug dealer, the offender was active in drugs, or drugs were present at the scene. ${ }^{21}$ This figure compares with a negligible number of officially reported nonlethal robberies. ${ }^{22}$

Are robberies involving illicit drugs more likely to lead to the death of the victim? We believe the answer is yes, because the much higher proba-

19 The following formula is used to determine relative dangerousness:

$$
\frac{a}{a^{\prime}} \times \frac{b^{\prime}}{b}=\text { differential dangerousness, }
$$

where $a$ and $b$ are the percentage of robbery deaths in two different locations (in this instance $a=$ residental and $b=$ street), and $a^{\prime}$ and $b^{\prime}$ represent the percentage of nonlethal robberies in those locations. Inserting the appropriate figures:

$$
\frac{36}{8} \times \frac{19}{51}=12.1
$$

${ }^{20}$ See Wesley G. Skogan, Citizen Reporting of Crime: Some National Panel Data, 13 Criminology 535, 541-44 (1976); and Michael J. Hindelang \& Michael Gottfredson, The Victim's Decision Not to Invoke the Criminal Justice Process in Criminal Justice and the Victim (William F. McDonald ed. 1976), at 74.

21 The figures for each of the variables in the robbery killing cases are in Appendix Table A3. A case was considered to have drug involvement if there was an affirmative or probably affirmative response to any of the three questions. The one-in-five figure probably underestimates drug involvement since the drug activity of offenders and the presence of drugs at the scene is unknown in a large proportion of these cases.

22 In only one of 360 cases was drug involvement indicated in the police report. 
bility that victim knows offender may motivate a killing to avoid detection or revenge, and because violence is commonplace with illegal drug traffic.

It would be a mistake, however, to say that the absence of noted drug involvement in nonlethal robbery statistics means such incidents rarely occur. Victims involved in illicit drugs would not be expected to report offenses to the police, especially when the object of robbery is the illegal commodity itself. The absence of reported nonfatal drug robberies simply tells us that official statistics cannot be used to estimate the frequency of nonlethal drug robbery.

Thus, the high volume of drug-related robbery fatalities provides evidence that drug robbery is more life threatening than other robbery events, but we lack any basis for estimating the frequency of drug rip-offs and therefore the extent to which drug robberies are more dangerous. Further, and of significance, the presence of the drug cases in the killing sample may invite misleading inferences when all killing cases are compared with nonlethal robbery. The fact that drug-related robbery killings are reported and nonlethal drug offenses are not included in robbery statistics tends to inflate the apparent death rate of all robbery events and of other specific types of robbery.

The problem of confounding differences in dangerousness with the underreporting or different classification of nonlethal events is substantial for two other major categories of potentially lethal robberies previously mentioned: those where the victim knows his offenders and robberies occurring in residential settings. In each case, it is plausible to suppose that the death risk associated with robbery events is higher than with the prototype street robbery, but comparing patterns of officially reported nonlethal robbery with robbery deaths is an inappropriate way of estimating differential dangerousness.

The factors associated with nontypical robbery killings-prior relationship, residential setting, and drug involvement-frequently occur together, as shown in Table 4. The locations associated with most nonlethal robbery, commercial and street settings, rarely lead to killings when the victim knows the offender or where there is strong evidence of drug involvement. ${ }^{23}$ This pattern of clustering persists when those motiveunknown killings that were reclassified as probable or possible robberies are added. ${ }^{24}$

23 Drugs are suspected of being involved in only one of the commercial robbery killings and only two street robbery killings. Some prior relationship between the victim and offender is indicated in 18 percent of the commercial killings and in 21 percent of the street killings.

${ }^{24}$ See Appendix Table A4. When a robbery involved more than one offender or victim, the offenders or victims or both were ranked by degree of involvement. For Table A4, the most involved offender was compared with the most involved victim. 
TABLE 4

Distribution of Drug Related and Nonstranger Robbery KiLLINGS BY RoBbery LOCATION

\begin{tabular}{lcc}
\hline \hline & Drug Related & Nonstranger \\
\hline Residential & 47 & 55 \\
Commercial & 6 & 14 \\
Street & 6 & 14 \\
Other & 41 & 18 \\
\cline { 2 - 3 } Total & 100 & 100 \\
$N$ & 17 & 22 \\
\hline \multicolumn{2}{l}{ Note._-Totals may not equal 100 due to rounding. }
\end{tabular}

The strong association between the location of a robbery killing and factors such as prior relationship or drug involvement provides a method for comparing fatal and nonfatal robbery events that partially controls for the biases introduced by the selective nonreporting of nonlethal robbery events. While many of the factors associated with different patterns of robbery killing are frequently not known, the location of the robbery event can usually be unambiguously determined. It should be possible, then, to make specific comparisons between fatal and nonfatal robberies where nonlethal events are frequently reported and to avoid the substantial biases introduced when other categories of robbery killing are included in aggregate totals.

Our first excursion into the use of location-specific estimates concerns the death rate from robbery. Earlier attempts at estimating a death rate, using total robbery deaths and an overall figure for nonlethal robberies, included a substantial margin of error because of killings that might have been robbery related and were not so classified by the police. Specifying the location of robberies narrows the margin of error substantially, as shown in Table 5. The death rates estimated in the table differ from earlier aggregates in three respects. First, the deletion of residential robbery killings lowers the rate of estimated robbery killing for nonresidential robbery. Second, the absence of questionable cases in commercial locations allows an estimated death risk for this category with a relatively small margin of error attributable to death classification problems. For street robbery, the large gap between minimum and maximum estimates persists, but the breakdown by location confirms that this problem is inherent in the data rather than attributable to inappropriate classification. Third, and most striking, the specific death rate from commercial robberies is about eight times that estimated for street robbery. 
TABLE 5

Robbery Killings, Robbery Events, and Estimated Death Risks by Location, Chicago

\begin{tabular}{lccc}
\hline \hline & $\begin{array}{c}\text { Robbery Killings } \\
\text { Sample Year* }\end{array}$ & $\begin{array}{c}\text { Estimated Robbery } \\
\text { Events (1983) }\end{array}$ & $\begin{array}{c}\text { Range of Robbery } \\
\text { Death Rates per } \\
\text { Thousand Events }\end{array}$ \\
\hline Residential & $34-43$ & $\dagger$ & $15.2-16.1$ \\
Commercial & $17-18$ & 1,116 & $1.4-2.2$ \\
Street & $19-31$ & 13,990 & $\dagger$ \\
Other & $24-34$ & $\dagger$ & \\
\hline
\end{tabular}

* Lower estimate includes only classified cases; high estimate includes all possible cases.

† No adequate sample.

Social Distance and Robbery Killing. The popular conception of robbery and of robbery homicide imagines a substantial social distance between victim and offender. Most homicide grows out of the victim's relationship with acquaintances and intimates. In theory, a potential victim's social status and choice of acquaintances has a significant effect on victimization risks. But the frightening collateral message of robbery as a stranger crime is that who one is or whom one knows is less important in determining chances of victimization.

We have already reported on one element of the social distance between victim and offender in robbery killing, the existence of a prior relationship between the victim and offender. This section uses alternative indicators of social distance between victim and offender for robbery killings subclassified by the location of the event.

Table 6 launches the analysis by summarizing the frequency of nonstranger relationships between victim and offender and three other possible indicators of social distance between robbery and victim by the location of the robbery leading to death.

None of the factors reported in Table 6 is an unambiguous indication of social distance, but all seem relevant to the concept as it is usually understood. The aggregate picture both confirms the image of robbery as a crime generally involving social distance and suggests that that perception needs significant qualification. Seven out of ten killings involve a victim with no prior relationship to the offender and two out of three involve a victim and offender more than ten years apart in age. Yet three quarters of our homicides involve a victim and offender of the same race and eight out of ten involve males as both victim and offender. With respect to sex and race, these findings suggest that robbery killing victims are disproportionately selected from Chicago's population to match the race and sex of the offender. 
TABLE 6

Percentage of Robbery Killings by Location Displaying Indications of Victim-Offender Social Distance

\begin{tabular}{lcccc}
\hline \hline & $\begin{array}{c}\text { Victim and } \\
\text { Offender Are } \\
\text { Not Strangers }\end{array}$ & $\begin{array}{c}\text { Victim and } \\
\text { Offender Are } \\
\text { of Same } \\
\text { Race }\end{array}$ & $\begin{array}{c}\text { Victim and } \\
\text { Offender Are } \\
\text { within Ten } \\
\text { Years in Age }\end{array}$ & $\begin{array}{c}\text { Victim and } \\
\text { Offender } \\
\text { Both Males }\end{array}$ \\
\hline Residential & 55 & 76 & 26 & 64 \\
Commercial & 23 & 42 & 22 & 92 \\
Street & 20 & 81 & 27 & 94 \\
Other & 18 & 72 & 50 & 88 \\
All robbery & 31 & 73 & 33 & 82 \\
killings & 72 & 78 & 67 & 78 \\
$N$ & & & & \\
\hline
\end{tabular}

Cross-tabulating measures of social distance by the location of the robbery produces a clearer picture. Residential robbery killings produce low values of social distance between victim and offender: a majority of these events involve nonstrangers, and eight out of ten do not cross racial lines. Commercial robbery killings, by contrast, involve strangers four-fifths of the time and cross racial lines in 43 percent of the cases where the offender's race is known.

Killings generated by street robbery occupy a middle position in measures of social distance. When the analysis is confined to police-classified robbery killings, a quarter of all victims know the offender, and approximately the same proportion of cases involve victim and offender within ten years of each other in age. These findings are consistent with substantial social distance between victim and offender in most cases. Almost all of the street killings, however, involve male victims and nine out of ten involve a victim and offender of the same race, a pattern that indicates that the risk of robbery death is not distributed randomly throughout the community. ${ }^{25}$ Adding probable and possible robberies to the street and residential robbery killings tends to decrease the estimated social distance between victim and offender. ${ }^{26}$

Weapon Use and the Robbery Death Rate. A striking example of the importance of location-specific comparisons concerns the question whether the weapon used in robbery affects the chance that a victim death will result. Table 7, comparing all officially classified robbery deaths and

\footnotetext{
${ }^{25}$ According to the 1980 census, the racial composition of Chicago was 40 percent black, 14 percent Hispanic, and 46 percent white and other. The nonfatal robbery sample in our study included 69 percent blacks, 10 percent Hispanics, and 22 percent whites and others.

${ }^{26}$ See Appendix Table A5.
} 
TABLE 7

ROBbery KilLINGS aNd Robberies, by Weapon

\begin{tabular}{lcc}
\hline & Killings & Nonlethal \\
\hline Gun & 59 & 43 \\
Knife & 19 & 14 \\
Other weapon & 15 & 8 \\
Personal force & 7 & 35 \\
Total & 100 & 100 \\
$N$ & 93 & 324 \\
\hline
\end{tabular}

our sample of robbery events, gives the impression that the choice of weapon has no influence on death rate. Robberies involving only personal force account for 35 percent of nonlethal offenses but only 7 percent of all fatalities. The death rate from such events is approximately one tenth that of robberies committed with guns, knives, or other weapons. But the death risk associated with all weapon types (measured by dividing a particular weapon's share of death cases by its share of nonlethal cases) seems indistinguishable. ${ }^{27}$ Thus, whether or not a weapon is used in a robbery is a major influence on the death rate, but it appears that the choice of what specific weapon has no further influence on the risk of fatality.

This finding is inconsistent with the scant prior research on the question of weapon dangerousness. ${ }^{28}$ The lack of differential between weapons is also a demonstrable artifact of including residential cases (without a substantial representation in the nonlethal sample) and aggregating all robbery types into a single category.

Table 8 separately compares fatal and nonfatal robberies for street, commercial, and other locations using the same data as employed in Table 7. Shootings dominate the robbery death statistics by specific location, ranging from two-thirds of all street robbery killing to more than 80 percent of the commercial and other location robbery deaths. The ratio of killings to nonlethal robberies discussed in the previous paragraph estimates a death rate per hundred gun robberies more than twice as high as

27 The death rate per thousand robberies associated with use of each type of weapon is 1.9 for guns, 2.1 for knives, and 1.7 for other weapons. The death rate associated with personal force is only .14 .

${ }^{28}$ See Philip J. Cook, The Effect of Gun Availability on Robbery and Robbery Murder: A Cross-Section Study of Fifty Cities, in 3 Policy Studies Review Annual (Robert H. Haveman \& B. Bruce Zellner eds. 1979), at 773-776; and Zimring, supra note 1, at 321-26. 
TABLE 8

Percentage Distribution of Robberies and Robbery Killings by Location and Weapon

\begin{tabular}{|c|c|c|c|c|c|c|}
\hline & \multicolumn{2}{|c|}{ COMMERCIAL RobBeries } & \multicolumn{2}{|c|}{ STREet Robberies } & \multicolumn{2}{|c|}{ Other RobBeries } \\
\hline & Killings & Nonlethal & Killings & Nonlethal & Killings & Nonlethal \\
\hline Gun & 81 & 67 & 67 & 39 & 83 & 43 \\
\hline Knife & 13 & 11 & 11 & 15 & 13 & 15 \\
\hline \multicolumn{7}{|l|}{ Other } \\
\hline weapon & 6 & 6 & 17 & 8 & $\ldots$ & 8 \\
\hline \\
\hline force & $\ldots$ & 17 & 6 & 39 & 4 & 34 \\
\hline Total & 100 & 100 & 100 & 100 & 100 & 100 \\
\hline$N$ & 16 & 36 & 18 & 150 & 24 & 109 \\
\hline
\end{tabular}

the death rate for knife robbery in street and other robbery locations. ${ }^{29}$ The flat pattern in the aggregate totals obtains because a third of all residential robbery killings were committed with knives, whereas only three of the twenty-seven reported nonlethal robberies occurring in nonresidential settings involved a knife.

If residential robbery killings are excluded from the sample, guns account for 76 percent of robbery deaths. Using the full year statistics on reported robbery for 1983, guns accounted for 27 percent of classified robberies. Knives account for 13 percent of robberies and 12 percent of robbery deaths. This produces a restated estimate that gun robberies known to the police (excluding residential cases) are three times as likely to result in death as robbery committed with knives, the next most dangerous weapon in these statistics.

As previous work has shown, estimates of weapon dangerousness based only on reported cases tend to underestimate the lethality of guns compared to other weapons because a higher proportion of nonlethal gun robberies are reported to and by the police. One previous study has suggested that the extent to which gun robberies are more dangerous than knife robberies is at least three to one when estimates of weapon use in nonlethal robberies are taken from victim surveys rather than police statistics. ${ }^{30}$ The location-specific estimates developed from this study are consistent with these earlier approximations.

\footnotetext{
29 In street locations gun robberies are 2.3 times more lethal while in "other" locations they are 2.2 times more lethal.

30 Zimring, supra note 1 , at 325 .
} 
TABLE 9

Robberies and Robbery Killings by Location and Percentage Female Victims

\begin{tabular}{lcc}
\hline \hline & Robbery Killings & Robberies \\
\hline Residential & 38 & 45 \\
Commercial & 7 & 38 \\
Street & 6 & 28 \\
Other & 11 & 41 \\
All cases & 19 & 34 \\
$N$ & 94 & 360 \\
\hline
\end{tabular}

Gender, Resistance, and Robbery Death Risk. Another topic on which location-specific comparisons prove useful is the relationship between the victim's sex and the death risk from robbery. Table 9 provides the pertinent data.

Female robbery victims range from 28 percent of all reported street cases to 45 percent of the small and problematic sample of nonfatal residential robberies. Robbery killings, however, involve male victims predominantly. Excluding residential robbery killings, female victims are rare: 7 percent of commercial robbery homicides, 11 percent of other location robbery killings, and 6 percent of the street robbery killings in Chicago during a twelve-month period.

One method of analyzing these patterns is to estimate the relative death risk of robbery for each sex using the frequency of fatal and nonfatal events, the approach used in our discussion of weapon dangerousness. By this method, commercial robberies with female victims result in death at less than an eighth the rate of commercial robberies with male victims. Street robbery, with only one female fatality, is six times less deadly than male victim street robbery, and other location robberies involving female victims are also about one sixth as deadly as those with male victims.

Much of the difference by gender is related to differences in perceived and actual victim resistance. Robbers may think that women are likely to offer less resistance to robbery and thus they will use less force at the outset of a robbery. Further, the large difference in death rate by sex and the persistence of this pattern in gun robbery suggest that actual resistance is much less frequent among female robbery victims. ${ }^{31}$

Table 10 introduces the analysis of resistance and robbery death by showing the pattern of resistance for robberies and robbery killings. The robbery event was classified into one of three categories: no resistance

31 While women are 30 percent of the victims in nonfatal gun robberies, they are only 13 percent of the robbery killings. 
TABLE 10

Percentage Distribution of Robberies and Robbery Killings by Resistance

\begin{tabular}{lcc}
\hline \hline & Robbery Killings & Robberies \\
\hline No resistance & 34 & 82 \\
Passive noncooperation & 11 & 10 \\
Active noncooperation & 55 & 8 \\
$N$ & 65 & 348 \\
\hline
\end{tabular}

noted, passive noncooperation (the victim usually says he or she has no money), and active noncooperation (including refusal, flight, and physical force).

Loss of life in robbery is strongly associated with active victim resistance. Only 8 percent of the robbery cases resulted in this classification compared with 55 percent of the death cases. Put another way, active noncooperation is associated with a death risk from robbery approximately fourteen times as great as cooperation or passive noncooperation. Passive noncooperation is about twice as likely to produce a lethal outcome as no resistance in our data. This pattern holds when the cases are separately analyzed by robbery location. ${ }^{32}$

The resistance estimates discussed above are based on robbery cases reported to and by the Chicago police. Because successfully resisted robbery attempts are less frequently reported to the police by victims, the difference in death rates between active resistance and nonresistance cases may be overstated.

An imperfect method for correcting nonreporting biases using victim survey data confirms the large difference in death risks associated with resistance. The comparison is imperfect because the survey data exclude commercial cases, fail to distinguish between active and passive resistance, and include many incidents of ambiguous seriousness. ${ }^{33}$ For gun robbery attempts in the victim survey, a total resistance rate (active and passive) of 24 percent is reported by Block and Block. ${ }^{34}$ Using this esti-

\footnotetext{
32 Active resistance accounted for 82 percent of commercial robbery killings but only 8 percent of the general robbery incidents in commercial settings. Active resistance was present in 54 percent of all street robbery killings but only 9 percent of street robberies. Street robberies involving active resistance were estimated to be sixteen times more likely than nonresistance cases to end in the death of the victim. The multiple for commercial cases, involving a sample of only eleven killings, was estimated at forty-nine.

${ }^{33}$ See Block \& Block, supra note 9.

${ }^{34}$ Id. at 631 , fig. 6.
} 
mate of resistance, the death rate from gun robberies involving undifferentiated resistance is 8.6 times the level found in nonresistance cases. ${ }^{35}$

Finding active resistance associated with a much higher death risk is not the equivalent of proving a causal relationship between the victim's resistance and increased risk of death. In some cases, the lethal intentions of the robber may provoke an otherwise passive victim rather than that the active resistance transforms the robber's intent. Our inability to make confident assessments of the sequence of resistance in the killing caseswhether resistance altered or resulted from the offenders' intentions to injure-limits our ability to estimate with precision how many additional deaths are generated by victim resistance.

But our current data suggest the independent role of resistance is substantial. Even if half of all robbery killings associated with active resistance would have occurred in any event, active resistance would still escalate the risk of death by a factor of between three and four. ${ }^{36}$ Under such circumstances, prudent victims should avoid most active noncooperation when involved in armed robbery. And the strong relationship between victim's gender and the death risk from robbery is further circumstantial evidence that resistance provokes higher death risks in armed robbery.

\section{Robbery with Injury}

Between the high volume of robbery events that do not injure and the relatively small number of robberies that kill there are a substantial number of cases that produce physical injuries in their victims of various degrees of seriousness. Unlike the robbery killing and police-classified robbery event, there is no special category in official statistics for robberies causing physical injury to the victim. Surveys of victims of violent crimes have provided some data on the incidence and correlates of robbery producing nonfatal injury, but the phenomenon remains understudied. ${ }^{37}$

35 Thirty-three deaths resulted from gun robberies with undifferentiated resistance, twelve deaths where no resistance was involved. If the 24 percent resistance estimate is applied to nonfatal gun robberies, the ratio is thirty-three with resistance to 103 without.

$$
\frac{33}{12} \div \frac{33}{103}=8.6 \text {. }
$$

36 The precise estimate depends on the choice of method. Eliminating passive resistance cases, and transferring half of all active resistance deaths to the no resistance category. produces an estimate that resistance cases are 4.7 times as likely to cause death as the no resistance robberies.

${ }^{37}$ See, for example, Michael R. Gottfredson \& Michael J. Hindelang, Bodily Injury in Personal Crimes, in Sample Surveys of the Victims of Crimes (Wesley G. Skogan ed. 1976), at 74-77; and Philip J. Cook, A Strategic Choice Analysis of Robbery, in id. at 181-85. 
This research provides two data sets on the incidence and distribution of robbery with injury. Our sample of police-classified robberies, thirty cases per month for the study year, provides some cases of robbery leading to injury and an estimate of the prevalence of physical injury in police-classified robberies. Table 11 sets out this distribution. The base rate of injuries leading to hospital attention is low, 10.2 percent of our sample of classified robberies. The distribution of injuries in robbery events also seems skewed toward the less serious end of the spectrum: only 19 percent of all injury robberies as we define them probably resulted in hospital admissions, ambulance calls, or other indications of serious wounding, a rate per hundred robberies of 1.9 .

Because the rate of robbery injuries is relatively low, and skewed toward non-life-threatening cases, we collected a supplementary sample of robberies that led the victim to seek hospital care or otherwise showed indications of seriousness. The first thirty such cases in a month were selected by the Detective Division of the Chicago Police Department for inclusion in this sample. ${ }^{38}$

Our sample uses a broad definition of victim injury. Only one in five of the injury cases was regarded as unambiguously serious. For this reason, it is important not only to make comparisons between noninjury and injury robberies but also to contrast those robberies producing some injury with the minority of robbery injury cases that require hospital admission.

Table 12 provides the distribution by location of robberies, robberies with injuries, robberies with injury requiring hospital admission, and robbery deaths. Each robbery location has its own distinctive pattern as comparisons proceed from all robberies through degrees of injury to fatalities, from left to right in the table. Robberies in residential settings, one out of twelve police reported robberies, are involved in only one out of every twenty robberies with injury. When injuries do occur, they are more frequently associated with the serious cases, accounting for 7 percent of the hospital admission and ambulance cases in our sample. With

${ }^{38}$ Incident reports filled out by Chicago police whenever a crime is reported include a box to be checked if a victim is taken to a hospital. Only reports so checked were included in the supplementary sample. Copies of all robbery incident reports are sent from the field to the Crime Analysis Unit of the Detectives' Division at the police department's central headquarters. There they are reviewed by a detective knowledgeable about robberies who searches for patterns to bring to the attention of field personnel. At the beginning of each month, this detective selected for inclusion in our supplementary sample the first thirty cases he examined where a check indicated that the victim had been taken to a hospital. The reports came in small batches from the field offices and were examined by the detective in the order received. Since it took a number of days for the sample to be completed each month, it is likely that this convenience sample approximates a random one quite closely. 
TABLE 11

Percentage Distribution of Injuries in Chicago Robbepjes

\begin{tabular}{lr}
\hline \hline No report of injury & 71.4 \\
Complaint of injury, no resort to hospital & 18.3 \\
Sought aid at hospital & 8.3 \\
Probably admitted to hospital or serious wound & 1.9 \\
Total & $\frac{100}{360}$ \\
$N$ & \\
\hline & Note.-Total does not equal 100 due to rounding.
\end{tabular}

TABLE 12

Percentage Distribution of Robberies, Robberies with Injury, AND RoBbery KiLlings by LOCATION

\begin{tabular}{lcccr}
\hline \hline & Robbery & $\begin{array}{c}\text { Robbery with } \\
\text { Injury }\end{array}$ & $\begin{array}{c}\text { Serious } \\
\text { Injury }\end{array}$ & Death \\
\hline Residential & 8 & 5 & 7 & 36 \\
Commercial & 11 & 6 & 2 & 18 \\
Street & 48 & 70 & 69 & 20 \\
Other & 33 & 20 & 22 & 100 \\
\cline { 2 - 5 } Total & 100 & 100 & 100 & 94 \\
$N$ & 359 & 345 & 54 &
\end{tabular}

that exception, the proportion of officially reported nonfatal robberies involving residential locations does not increase when injury or serious injury cases are isolated, and the percentage of residential cases never approaches the 36 percent of robbery killings associated with residential settings.

Commercial robberies, responsible for 11 percent of the main sample of nonlethal robbery events, account for less than half that proportion of robberies with injury and no reported cases of serious injury in our sample. Unlike nonfatal residential robberies, commercial robberies are usually reported and classified as such. Such robberies apparently involve behavioral dynamics and weapons that generate substantial death risks but small risks of injury. ${ }^{39}$

39 The importance of weapon use is supported by Appendix Table A6, which demonstrates that injury cases in commercial settings as in other settings generally occur where guns are absent. 
Street robbery, by contrast, is associated with relatively high risks of injury and low risks of death. Street incidents account for half of all reported robberies, two-thirds of the robberies with injury and hospital admission cases, but only 20 percent of the deaths. This pattern is unlikely to result from reporting difficulties. Adding in all possible street robbery killings still leaves us with street robberies responsible for twice the proportion of robbery injuries as of robbery deaths. ${ }^{40}$

Table 13 reports the distribution of robbery, robbery injury, and death cases by race and sex of victim. White victims with other than Hispanic surnames account for one-fifth of noninjury robberies, a quarter of robbery injuries, only 15 percent of the hospital admission cases, and 26 percent of the deaths. The somewhat higher proportion of white victim cases in the death category is attributable to the high death rate and low injury rate associated with commercial robberies, a category that includes a majority of the white victim deaths in Chicago. ${ }^{41}$

Black victimization accounts for at least 60 percent of the robbery cases in each category of victim harm, with higher concentrations among the hospital admission group than the other injury or death cases. Hispanicsurname victims experience a larger relative frequency of robbery injuries than either noninjury robberies or robbery deaths. ${ }^{42}$

Two aspects of the pattern of victimization by sex merit special attention. First, male victims outnumber female victims in reported robberies by a two-to-one margin, and all that is known about probabilities of reporting to the police suggests that this is certainly no artifact of sex-based reporting. This two-to-one difference in robbery victimization roughly doubles again with respect to the incidence of injury or death, where the difference in risk between the sexes approaches four to one. Adding information on two categories of nonlethal injury thus underscores the strong difference in risk of aggravation by sex noted earlier.

Table 14 provides the distribution of weapons used across the spectrum from uncomplicated robbery to robbery killing. Guns dominate robbery killings statistics and account for a plurality of uncomplicated robberies as previously noted and discussed..$^{43}$ Gun cases are underrepresented in the robbery injury sample, consistent with previous studies, but show up more than twice as often in the most serious category of robbery injuries.

\footnotetext{
40 Adding all possible street robbery killings increases the percentage of street killings to 24 percent.

${ }^{41}$ See Appendix Table A6.

42 Our first guess was that Hispanics would be overrepresented in street robberies, but this turns out on further examination not to be the case. The percentage of robberies taking place in street settings is 56 percent Hispanics, 48 percent whites, and 58 percent blacks.

${ }^{43}$ See Table 7 and accompanying text, supra.
} 
TABLE 13

Percentage Distribution of Robberies, Robberies with Injury, and Robbery Killings by Race and Sex of Victim

\begin{tabular}{lcccr}
\hline \hline & Robberies & $\begin{array}{c}\text { Robbery } \\
\text { Injuries }\end{array}$ & $\begin{array}{c}\text { Serious } \\
\text { Injuries }\end{array}$ & Deaths \\
\hline Victim Race/ & & & & \\
$\quad$ Ethnicity: & 20 & 24 & 13 & 26 \\
White (non-Hispanic) & 69 & 61 & 81 & 62 \\
Black & 10 & 15 & 6 & 4 \\
Hispanic & 2 & 1 & 53 & 95 \\
Other & 336 & 336 & 93 & 81 \\
$N$ & & & 7 & 19 \\
Sex: & 66 & 80 & 54 & 95 \\
Male & 34 & 20 & & \\
Female & 360 & 342 & & \\
$N$ & & &
\end{tabular}

TABLE 14

Percentage Distribution of Robberies, Robberies with Injury, and Robbery Killings by Weapon

\begin{tabular}{lcccr}
\hline \hline & Robberies & $\begin{array}{c}\text { Robbery } \\
\text { Injuries }\end{array}$ & $\begin{array}{c}\text { Serious } \\
\text { Injuries }\end{array}$ & Deaths \\
\hline Gun & 43 & 15 & 34 & 59 \\
Knife & 14 & 14 & 19 & 19 \\
Other weapon & 8 & 17 & 15 & 15 \\
Personal force & 35 & 54 & 32 & 100 \\
$\quad$ Total & 100 & 100 & 53 & 93 \\
$N$ & 324 & 339 & 100 \\
\hline
\end{tabular}

Knives account for the same proportion of robberies and robbery injuries, 14 percent, and one-fifth of the serious injury and death cases. Removing residential robbery deaths to provide for continuity across the samples reduces knife killings to 10 percent of the total. Robberies without weapons account for more than a third of all events, more than half of all injuries, and 31 percent of even the hospital admission cases. A sharp drop-off occurs in the transition from hospital admission cases to recorded fatalities.

A summary statement of the relationship among the various robbery harm categories would emphasize three elements: (1) the overlap between patterns of nonlethal robbery without injury and those leading to injury; (2) the sharp differences between robbery killings and nonlethal robberies; and (3) the even sharper differences between robbery killing cases 


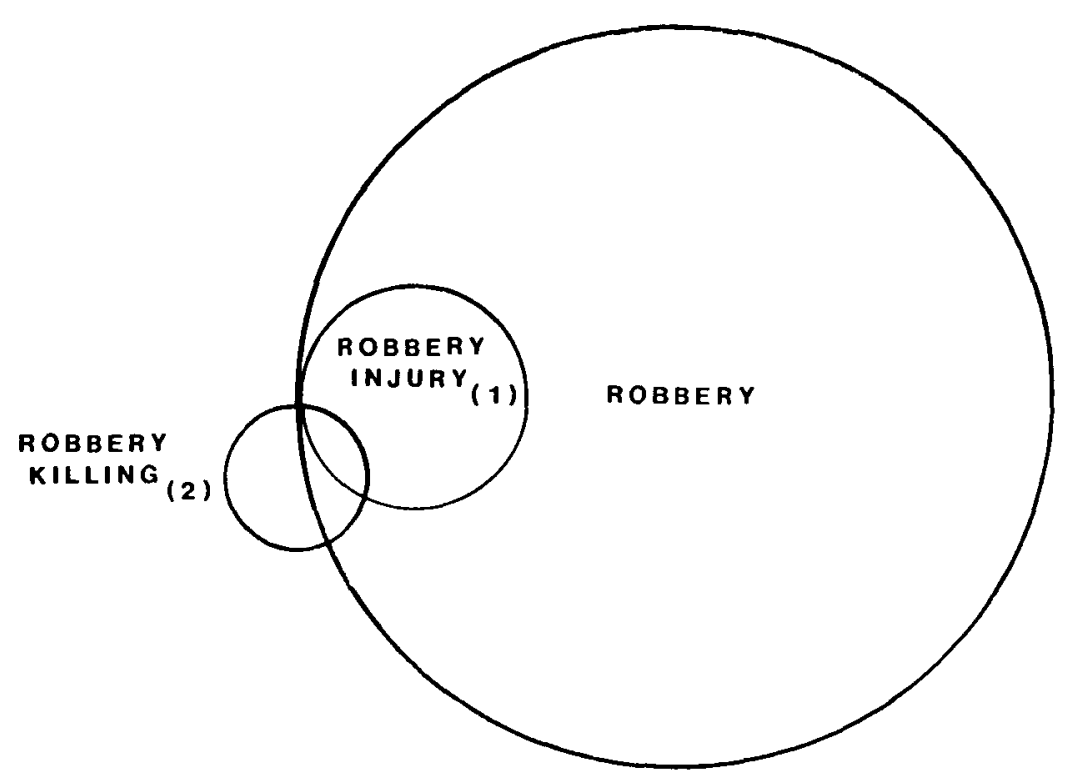

FIGURE 2.-The relationships among patterns of robbery, robbery with injury, and robbery killing. (1) Drawn to three times actual scale. (2) Drawn to thirty times actual scale.

and robbery injury cases. Figure 2 attempts to visually portray the noted relationship among these three categories.

The profile of robbery injury cases closely follows general patterns of nonlethal robbery: there are more male victims, more street cases, and fewer guns, but the two samples are similar in most other respects. In contrast, half of all robbery killings involve situations and locations not frequently found in nonlethal robbery. The sharpest disjunction in pattern occurs when robbery injury cases are compared with reported cases producing robbery victim deaths.

\section{Groups and Robbery Outcome}

The information available about offenders in this study is limited by low clearance rate for nonfatal robbery. On one issue, however-the number of offenders involved-a fair if imperfect comparison between lethal and nonlethal robbery is permitted by the higher clearance rate associated with the killings and the accuracy of victim reporting in the nonfatal cases. Table 15 presents a distribution of robbery cases by number of offenders involved, for robbery killing, robbery with injury, and robbery.

The table makes two points. First, robbery of all kinds is a group offense. Less than 40 percent of robbery events in our sample, regardless 
TABLE 15

Percentage Distribution by Number of Offenders, All Locations

\begin{tabular}{|c|c|c|c|}
\hline & Robbery Killings & Robberies with Injury & Robberies \\
\hline 1 & 34 & 30 & 38 \\
\hline 2 & 38 & 33 & 38 \\
\hline 3 & 17 & 23 & 17 \\
\hline 4 & 10 & 5 & 4 \\
\hline 5 & $\ldots$ & 4 & 1 \\
\hline 6 & 1 & 2 & 1 \\
\hline 7 & ... & $\cdots$ & 1 \\
\hline More than 7 & $\ldots$ & 2 & $\ldots$ \\
\hline Total & 100 & 100 & 100 \\
\hline$N$ & 79 & 337 & 351 \\
\hline
\end{tabular}

of outcome, involve a lone offender. Second, there are no clear indications of significant differences between robbery, robbery injury, and robbery killings in the relative concentration of group offenses.

Table 16 attempts to take this analysis one step further, by reporting the percentage of cases with more than one offender on a location-specific basis, deleting the problematic residential category from the analysis.

Table 16 is superior to the initial analysis because it reports the group participation for each separate location. To make this possible, however, we must divide robbery events into individual and group to avoid the problem of insufficient numbers.

And even with the compression of cases into solo and group categories, the number of commercial cases in each category is insufficient for confident statistical analysis. Still, the preliminary indications with respect to the commercial cases deserve mention. Less than a third of the robberies without victim injuries involve more than one offender, and more than three-quarters of the commercial robberies involving significant victim injury or victim death are group related.

Larger samples will be needed to confirm whether this pattern is significant. Intuitively, it might make sense: commercial establishments are frequently in a better position to defend themselves from robbers than individuals in street or other locations. That is one reason successful commercial robberies more frequently involve guns. The lone robber may frequently be at a disadvantage relative to the target establishment, which diminishes his capacity to injure or kill his victim.

The lessons of Table 16 are consistent and worthy of note. The presence of more than one offender is not associated with significant differences in the probability of victim injury or death. But the analysis of 
TABLE 16

Percentage of Cases with More Than One Offender by location and Case Type

\begin{tabular}{|c|c|c|c|c|c|c|}
\hline & \multicolumn{2}{|c|}{ RobBery Killing } & \multicolumn{2}{|c|}{ ROBBERY WITH INJURY } & \multicolumn{2}{|c|}{ ROBBERY } \\
\hline & Percentage & $N$ & Percentage & $N$ & Percentage & $N$ \\
\hline Commercial & 75 & 12 & 77 & 17 & 30 & 37 \\
\hline Street & 75 & 16 & 72 & 235 & 70 & 182 \\
\hline Other & 72 & 25 & 63 & 68 & 64 & 105 \\
\hline
\end{tabular}

larger samples, cross-tabulating group involvement by weapon and dealing separately with constellations of two, three, and four or more robbers, may uncover significant differences lying beneath the apparent similarity.

\section{E. The Apprehension of Offenders: An Unresolved Puzzle}

This study was not designed to be a detailed investigation of the factors that produce arrests for robbery, and our capacity to illuminate the process of police work in robbery cases is extremely limited. Within these limits, there is merit in examining what data we have to highlight issues that future research should address.

We begin (in Table 17) with the overall figures on clearance by the police for robbery, robbery with injury, and robbery killing. ${ }^{44}$

The general pattern is clear, if not easily explained. Approximately one of every ten robberies reported to the Chicago police is listed as solved within two months of the event. There is no significant difference between clearance rates for unaggravated robberies and for those resulting in injury to the victim, but the clearance rate for robbery killing is five times as great as for other robbery. This dramatic difference in clearance rates is the focus of the analysis that follows, in which we attempt to explain the distinction, largely without success.

Earlier sections of the study show the disjunction between patterns of robbery killing and patterns of reported nonlethal robbery. Seeking some of the explanation in the different representation of various types of robbery in the killings cases seems a logical next step, as shown in Table 18.

The two striking elements of the table are the evenness of pattern for clearance rates for all types of robbery killings and the consistency in the sharp contrast between fatal and nonfatal robbery. Since residential rob-

\footnotetext{
44 Clearance rates can be measured in several ways, depending on whether they include only cases that resulted from police investigation, or in addition either cases reclassified from robbery to some other crime or cases that were considered unfounded. This figure represents the percentage of cleared cases by investigation as a percentage of those cases determined by investigation to have actually involved robberies.
} 
TABLE 17

Percentage Clearance by Type of Robbery

\begin{tabular}{ccc}
\hline \hline Robbery & $\begin{array}{c}\text { Robbery } \\
\text { with Injury }\end{array}$ & $\begin{array}{c}\text { Robbery } \\
\text { Killing }\end{array}$ \\
\hline 13 & 10 & 57 \\
\hline
\end{tabular}

TABLE 18

Clearance Rates by Robbery Location

\begin{tabular}{lcc}
\hline \hline & Robbery & Robbery Killing \\
\hline Residential & 13 & 56 \\
Commercial & 17 & 53 \\
Street & 11 & 61 \\
Other & 14 & 59 \\
\hline
\end{tabular}

TABLE 19

Robbery Killing Clearance Rate by Case Characteristics

\begin{tabular}{ll}
\hline \hline No prior relationship established* & 52 \\
Prior relationship** & 68 \\
Not drug related* & 55 \\
Drug related* & 65 \\
Police-classified robbery & 57 \\
Possible or probable robbery & 14 \\
\hline
\end{tabular}

* Police classified robbery cases only.

bery killings contain a larger proportion of the special patterns discussed earlier, the even pattern by location sustains rather than resolves the puzzle of the clearance gap.

A more direct way of examining the effect of robbery killing case characteristics on clearance rates is an analysis of robbery killing clearance rates by type of robbery, as shown in Table 19 .

The differences noted, with higher clearance rates for less typical robbery killings, should tend to enlarge the differences between solution rates for typical robberies and the killing cases. Yet the magnitudes of difference are slight, and the sharp contrast between successful solutions in killings and other cases remains to be explained.

One relatively simple explanation of different rates of solution is the greater amount of police effort invested in robbery killing cases. One need only thumb through a typical homicide file to comprehend that qualitative 
dimensions separate the detective work generated by a killing from all other frequent crimes. Might the difference in clearance rates simply reflect different returns on different investments?

Our tentative answer is no, although the data available are woefully inadequate to address the issue completely. Table 20 uses one indirect measure of the product of investigative work by comparing the time lapsed between crime and solution for cleared robbery and robbery killing cases. The theory is that extra effort will pay off over time in a greater proportion of cases solved after the dust has settled. This turns out not to be true. The pattern for cleared cases in both categories is remarkably even over time. There is no eventual, long-term advantage accruing to the more thoroughly investigated killings; the advantage is there all along. Five times as many killings are cleared during the first two days after the event and the same advantages hold when two months have elapsed. Extra investigative effort may reap dividends in ways that this time pattern does not detect. But a pattern in which the advantage of the killing cases had increased over time would be more consistent with the "extra effort" hypothesis.

The detailed examination of the determinants of robbery solutions requires a conscious design toward that end that this study did not carry. Such an effort can shed light both on the identification of robbery offenders and on the larger question of the marginal role of police resources in the control of violent crime.

\section{SOME ImPlications}

A first study of this kind is exploratory and its findings are necessarily tentative. Analysis over time, studies in other cities, and cross-sectional comparisons of a number of cities will be necessary to determine how many of the relationships we observed are fixed, how many are variable, and the extent of any variation in the multiple centers of American violence. Yet a preliminary assessment of the implications of these data for criminological theory and legal policy seems appropriate. That is the task of this section.

TABLE 20

Clearance Patterns by Time to Clearance of Robbery Killings and Robberies

\begin{tabular}{|c|c|c|c|c|c|}
\hline & $\begin{array}{l}\text { Less Than } \\
\text { Two Days }\end{array}$ & $\begin{array}{c}\text { Three to Five } \\
\text { Days }\end{array}$ & $\begin{array}{c}\text { Six to Ten } \\
\text { Days }\end{array}$ & $\begin{array}{c}\text { Eleven to Thirty } \\
\text { Days }\end{array}$ & $\begin{array}{l}\text { More Than } \\
\text { Thirty Days }\end{array}$ \\
\hline \multicolumn{6}{|l|}{ Robbery } \\
\hline killings & 27 & 35 & 40 & 50 & 57 \\
\hline Robberies & 5.8 & 7.2 & 7.8 & 11.7 & 13 \\
\hline
\end{tabular}




\section{Criminological Theory}

Commentators have often thought that both robbery and robbery homicide are subsets of a vague category known as "stranger-to-stranger" violence. ${ }^{45}$ This position may be both incorrect and misleading. It is incorrect, because behavior properly classified as robbery or aggravated robbery will in an important subset of events frequently involve nonstrangers.

A criminologist could respond that the inclusion of nonstranger cases is a product of legal nicety, that "real robbery" is a stranger-to-stranger phenomenon. One problem with this response is that it is tautological. If one defines a "real" robbery as necessarily involving strangers, any behavioral investigation based on that principle will confirm the premise regardless of the similarity in circumstance and motive between stranger and nonstranger events.

A second problem with that approach is that criminologists will use official statistics that may be based on aggregate totals of robbery killings to support theories where the same terms have different meanings. A sociologist may use trends in robbery killing as evidence of increases in stranger-to-stranger killing, even if the categories are more broadly construed by the reporting agencies that generate the statistics.

In fact, we do not know what share in the rise of classified robbery killings has occurred in the classic situations of nonlethal robbery (commercial and street locations), nor is it known to what extent they involve "pure" stranger situations. It is odd but appropriate that we cannot find the answer to that question until we regard it as worth asking.

A second point about theories of homicide deserves mention here, although it is only tangentially relevant to the findings of this study. It is amazing that so much discussion about homicide rates has been directed to the singular category of stranger-to-stranger homicide. If anyone were to propose an investigation of "acquaintance-to-acquaintance" homicide as a single behavioral category, the professional community would probably recommend psychiatric examination. When people kill people they do not know, the generating situations and motives may be importantly varied. The "stranger" label, while not meaningless, conveys only a single distinction where many distinctions and differences are necessary to understanding patterns of homicide.

A contrasting point should also be made. When reviewing the narratives of cases at the margin of robbery killing-an eclectic tour of life-

\footnotetext{
45 See Marc Reidel \& Margaret Zahn, The Nature and Patterns of American Homicide (Final Report to Nat'l Inst. on Just. 1983).
} 
styles in the depths of the urban ghetto-the problem whether or not to classify particular situations as robbery often struck us as unimportant. Sorting out robbery killings from other killings seemed relatively important given the similarities of structure, motive, weaponry, and sheer senselessness that unified the cases. Much of the "new American homicide" in the past two decades compromises a larger set of behaviors that blurs traditional distinctions between robbery and other homicides. This early in our research, we are unsure how long the new patterns have existed or how much they have expanded. But they are real and important.

The subcultures, situations, orientations, weaponry, chemical influences, and emotions that produce one category of killing in this context produce other categories as well. Violence that is essentially unplanned, and that frequently leads to killings, should not for theoretical purposes be separated into stranger and nonstranger categories in a rigid fashion and then analyzed in isolation. Unifying constructs should be searched for rather than imposed.

For example, while robbery is formally classified as a crime against property, a category such as "recreational violence" seems to us not only evocative but descriptive of a large number of violent events-including those that produce homicide-that span robbery and nonrobbery events. If the term sounds frivolous or abstract, the reader is invited into our files.

Having generated abundant measures of theoretical speculation, we turn our attention to one matter that can only be characterized as practical criminology: the wisdom of resistance in the context of armed robbery attempts. Our data are imperfect, circumstantial, and we believe conclusive. They are imperfect because our sample fails to capture a significant number of unsuccessful attempts that are not processed and classified as robberies in Chicago. They are circumstantial because the sequence of offender force and victim resistance is incompletely identified.

Still, the figures seem compelling. A far higher percentage of robbery killings than of robberies involve active victim resistance. Further, the concentration of killings among male victims rather than females suggests an obvious inference. When any potentially deadly weapon is involved, the correct answer to the implicit demand, your money or your life, is to provide the money.

It is a puzzle why resistance so frequently leads robbers to the risky path of inflicting lethal violence on their victims. ${ }^{46} \mathrm{~A}$ rational robber is best advised, on refusal, to seek a more compliant victim. But robbers often do not, and we hold out little hope that journal articles such as this will alter offender behavior. We suspect, in line with earlier theory, that

46 Block, Violent Crime, supra note 13 , at $78-88$. 
even if victim and offender in a robbery setting are strangers at the beginning, the victim's refusal to cooperate with the offender generates a contest of wills that helps explain an extraordinarily high rate of irrational violence on the part of the offender. ${ }^{47}$

One thing is clear: if life is dear, resistance to robbery with lethal weapons rarely makes sense. Unlike rape, the cost to the victim of compliance with the criminal demand is usually not momentous. In all but the most extraordinary circumstances, resistance to robbery demands under the threat of deadly weapons is unwise. Even when data are indeterminate, some chances are not worth taking.

\section{The Criminal Law}

We turn now, with some trepidation, to questions of penal policy that studies of the consequences of robbery might inform. Our findings are preliminary. The set of penal policy issues, principally two interrelated doctrines of felony murder, have long been a subject of criminal law debate. Yet some comment, even at this early stage, seems justified.

\section{Felony Murder}

In most American jurisdictions, what is popularly called the felony murder rule is really two rules. The first is the "malice rule," which holds that the intention to commit a forcible felony is a substitute for, or equivalent to, the mental state of malice usually required to hold an offender accountable for murder when causing another's death. In the array of knife, gun, bottle, baseball bat, and beating deaths that we observed in this study, the principal effect of bypassing a requirement of the mental state of malice is the generation of murder liability for accomplices in robbery for the lethal acts of their confederates. ${ }^{48}$

The second felony murder rule, usually provided by statute, is the automatic upgrading of any murder involving a robbery to the status of first degree $e^{49}$ as well as the automatic inclusion of the robbery as a circumstance that generates eligibility for the death penalty in state criminal codes that include capital punishment. ${ }^{50}$

${ }^{47}$ Id. at 86.

${ }^{48}$ See, for example, Wayne R. LaFave \& Austin W. Scott, Jr., Handbook on Criminal Law (1972), at 553-54.

${ }^{49}$ Id. at 566. See, for example, Cal. Penal Code $\S 189$ (West 1978).

so See, for example, Model Penal Code $\$ 210.6(3)$ (Proposed Official Draft 1962). In almost all states having a death penalty, some form of involvement in the commission of a robbery is used to justify imposition of the death penalty. See, for example, Cal. Penal Code $\S 190.2(a)(17)(i)$ (West 1983); Ill. Rev. Stat., ch. 38, § 9-1(b)(6)(c) (1983); and Tex. Penal Code Ann. $\$ 19.03(a)(2)$ (Vernon 1983). 
Malice. On the malice question the relevance of our data depends on the reason for the rule. The most powerful arguments both in favor of and against the so-called malice rule have little to do with the structure of robbery in the ordinary course of events. They are rather questions about how to balance ease of prosecution of co-felons against the injustices of implicating pacific accomplices in unanticipated lethal events. This tradeoff turns out to be extraordinarily difficult to investigate empirically. In most robbery killings, malice on the part of the lethal actor in a robbery scenario is anything but difficult to infer. The culpability of codefendants is more difficult to determine. Difficulty of proof is the reason the malice rule is both supported as necessary and attacked as unjust. The defenders of the rule note that the conclusive presumption is the only way to secure convictions of the accomplices in robbery offenses. Yet using difficulty of proof to reach that result increases the risk of possible injustice of a murder liability based solely on involvement in a robbery.

The low base probabilities of death associated with any combination of weapon and situation may seem to some readers to fall well below the malice standard. But here, too, the numbers do not compel a policy conclusion. It is our view, consistent with critical criminal law scholarship on this issue over a number of years, that a malice rule imputed to accomplices without evidence of complicity in the lethal act is incorrect, ${ }^{51}$ overbroad, and inappropriate. But this value preference is not derived from the present data, which add little to what is already known.

If, however, the malice rule is intended to save the lives of robbery victims, as prominent cases have recently stated, ${ }^{52}$ then our data suggest that the rule would serve its ends better if it were restricted to more lethal weapons. If the death rate is a good measure of the rate of accidental and negligent dangerous behavior, restricting the scope of the malice rule to robberies with guns, knives, and other equally dangerous instruments might be expected to produce offsetting effects with the benefits outweighing the costs. Some potential offenders, at present afraid of the wider malice rule, might take up robbery with personal force once the rule was cut back. Other personal-force robbers could be more careless in the conduct of robbery without lethal weapons. However, some robbers who might otherwise use lethal weapons might be channeled into robbery attempts without such weapons if the scope of the malice rule were so restricted.

\footnotetext{
st See, for example, Glanville Williams, Criminal Law: The General Part (2d ed. 1961), at 134-37.

${ }^{52}$ People v. Washington, 62 Cal. 2d 777, 781, 402 P.2d 130, 133 (1965).
} 
How much channeling behavior of this kind might take place is a matter of conjecture. In our view, the likelihood that the malice rule itself or any variation in it would have a measurable or significant influence on robbery behavior is very small. But that may be beside the point. If the saving of life is regarded as the primary purpose of the malice rule, the large differences noted in death rates make restricting its operation to deadly weapons a good bet. If such a restriction generated eight new personalforce robberies for every gun robbery converted into a personal-force crime, it would still save lives. Any smaller ratio would increase the benefits. Our sense of justice and statistics on relative death risk convergently argue for narrowing the rule.

Automatic Upgrading. We also believe that the information about robbery killings reported above undermines the basis for automatic liability for first-degree murder based on the existence of a predicate robbery. The many cases on the borderline between robbery and nonrobbery killing have been important both in the estimates of robbery homicide and in its implications for criminological theory. For the cases on the borderline, we felt that the ultimate classification made little difference. The conclusion seems appropriate for penal treatment as well.

Note that the punishment difference between second- and first-degree murder is enormous in most jurisdictions. ${ }^{53}$ If legislative trends toward very long prison terms as the minimum sanction for first-degree murder continue ${ }^{54}$ the importance of defining the boundary between first- and second-degree murder in a morally acceptable way becomes greater. A lethal drug rip-off is a terrible thing, but how much more so than a shooting generated by a fight for territorial rights to sell drugs? The old man purposefully and violently mugged but accidentally killed by a group of teenage boys may call for serious punishment. But the same punishment should not necessarily be meted out to the adolescent who used the lead pipe and to his accomplice who stripped the wallet and then stood by.

All three elements of the common modern equation that produces these results are individually problematic: the malice felony murder rule, the automatic treatment of robbery murderers as first degree, and the mandatory minimum punishment for all first-degree murders. They interact to produce an unprincipled rigidity that is even more troublesome.

53 See, for example, California (first degree, 25 years; second degree, 15 years), Cal. Penal Code, §190 (West 1983); Michigan (first degree, life imprisonment; second degree, some term of years), Mich. Comp. Laws Ann. $\$ 750.316$ (West 1983). See also Franklin E. Zimring, Joel Eigen, \& Sheila O’Malley, Punishing Homicide in Philadelphia: Perspectives on the Death Penalty, 43 U. Chi. L. Rev. 227 (1976).

${ }^{54}$ See, for example, Cal. Penal Code $\$ 190.2(a)(17)(i)$ (West 1983). 
The conceptual problems associated with the treatment of felony killings in the criminal law of homicide can, of course, be addressed without the benefit of empirical studies of robbery and robbery killing. The Chicago data add three dimensions to these theoretical concerns. First, the present study suggests that it is frequently quite difficult to determine whether a criminal homicide involves the collateral offense of robbery. Adding another element of guesswork in the fact-finding process, and then making momentous differences in outcome hinge on the characterization, is a recurrent problem according to our data.

The present study helps illuminate a second problem associated with rigid regimes and special treatment for classified robbery cases. The homicide so treated will frequently depart from the paradigm cases that inspired the legislation creating special treatment. In Chicago, difficult to characterize residential cases occur almost as often as commercial robbery and street robbery deaths combined. The important minority of nonstranger and drug cases are as frequent as commercial robbery killings. Some of these nonparadigm cases may be more hideous and more worthy of extreme penal sanctions than the archetypal robbery death. But these are not the classes of cases that inspired the special legislation.

Finally, to illustrate what we see as the problem of the penological relevance of the robbery category being associated with sharp differences in minimum prison terms, consider the following three case summaries:

1. The body of the victim, Jimmy Ray Christian, was found in the front seat of his parked car. Christian, who was twenty-nine years old, white, and married, had been shot once in the chest, probably two days earlier, while he was in the car. His wallet, its contents, and his car keys were not found by the police, but they did find several packets of a white powdery substance under the front seat. The doors of the car were locked when the police arrived. A neighbor saw the car pull over and park around 6:00 A.M. two days earlier. The victim had left his home around 5:00 A.M. that morning, according to his wife. He worked in Skokie, and, although he was not due to begin working until 7:30 A.M., he usually left home quite early. His wife reported knowing nothing about any illegal behavior or problems her husband might have had.

2. The victim, Irene Factor, was strangled to death in the living room of her home by Phillip Ramirez, a tenant, who she thought had come to pay her $\$ 50$ in back rent. After killing the victim, Ramirez, a twenty-year-old married Hispanic, took $\$ 60$ from the victim's purse along with some rent receipts and then fled. Factor was a seventy-five-year-old white woman who lived alone. Instead of bringing the money he owed her, Ramirez brought a length of clothesline, he later confessed to the police. After the victim berated him for failing to produce the money, he strangled her with the rope. 
The police reports do not indicate clearly the offender's intentions when he arrived at the victim's home. The presence of the clothesline suggests that from the start he may have intended to kill the victim. The fact that he killed her at a time when he was expected to visit her house suggests that he planned poorly or that he acted somewhat spontaneously.

The motive for the killing is also not clear. Ramirez had reason to be angry with his landlady: the day before she had announced that he would have to vacate the apartment. His minimal effort to obtain valuables after the killing is inconsistent with a planned robbery. The question whether the $\$ 60$ was taken after and independent of the fatal attack would seem crucial to the legal classification of the murder as felony related.

3. Charles Murdock was stabbed to death in the bedroom of his home by one or more offenders who remain unknown to the police. When the police arrived at the scene, they found that the victim's automobile was missing, and they suspected that items from his wallet had been taken. The car was later recovered on the other side of town. The victim, a fortytwo-year-old black college teacher, was a homosexual who also sold drugs. No drugs were found at the scene by police. The evening before the incident, the victim attended several parties. His naked body was found with as many as fifteen stab wounds. The bedroom was in disarray, apparently the result of a struggle.

The unclothed condition of the victim's body, the absence of any indication of forced entry, and the brutal nature of the killing suggest to the police that the offender and victim had some prior relationship. The motive for the killing and its relation to the taking of property remain unclear.

Cases 1 and 3 are taken from the "motive unknown" killings nominated as possible robberies in the rerating process. Case 2 is a police-classified robbery in a residential setting. We cannot claim that these three represent typical cases in the categories from which they are drawn. But they are not atypical of a substantial number of cases in each category.

Is case 2 a robbery killing? When the defendant formed the intent to take the money must be inferred from events. That he armed himself is consistent with an attempt both to steal and to attack without theft. A sharp difference in punishment tied to the robbery label makes guesswork more fateful. But the deeper point is that the intent to take property prior to the attack does not seem an important element in determining a just penalty in this case. The Ramirez crime might be an admirable candidate for the highest grade of murder liability, but the theft element seems low on the list of reasons why.

Is case 3 robbery murder or murder followed by theft? Should it make a great deal of difference? Our hunch is that the same prior relationship, motive for attack, and offender characteristics were present in either 
event. The same might well be true for case 1. Further, none of these cases apparently fits the image of robbery killing that motivated an automatic first-degree classification.

These cases are not infrequent. Any law professor worth his critical salt can draft a clever hypothesis to show the presence or absence of theft by force as a morally trivial element in a homicide that leads to widely different degrees of penal liability. What these data go a long way toward showing is that this has become a major problem in the administration of the criminal law of homicide, a problem not unrelated to concerns about plea bargaining, sentencing equity, equality of punishment, and the incoherence of the substantive criminal law here invoking its largest sanctions.

\section{Capital Punishment}

Adding insult to injury, the new jurisprudence of capital punishment in the United States places heavy reliance on the offender's commission of a forcible felony in differentiating murders ineligible for the death sentence from those eligible for execution. Statistically, killings committed during forcible felonies are the dominant basis for death sentences under postFurman $v$. Georgia statutes, ${ }^{55}$ and robbery killings are the substantial majority of the forcible felony killings that reach court. ${ }^{56}$ The difficulties associated with the automatic upgrading to first-degree murder are exacerbated when the difference between a lethal drug rip-off and other killings generated by drug subcultures becomes a life-or-death matter.

In the context of the administration of the death penalty, we cannot be comforted that normal processes of police classification and prosecutorial discretion will put matters right. It is difficult to know what principle should guide the law in constructing a hierarchy of culpabilities in felony killing. Should social distance make the difference? The property taken? What? There are reasons to suspect the capacity of decentralized discretionary decision makers to apply such distinctions. ${ }^{57}$ In fact, these reasons inspired the Supreme Court's ruling in Furman v. Georgia, and a succession of later cases that would suggest no permissible administration of the death penalty can rely on discretion to rescue it from penal incoherence. ${ }^{58}$ But constitutional mandates that the law must guide sentencing

\footnotetext{
55 See Franklin E. Zimring \& Gordon J. Hawkins, Capital Punishment and the American Agenda, ch. 4 (1986), forthcoming.

56 Twenty-four of the first thirty-eight executions in the United States involved convictions for killings committed in the course of robberies. Id.

57 Furman v. Georgia, 408 U.S. 238 (1972).

58 Gregg v. Georgia, 428 U.S. 153 (1976); and Coker v. Georgia, 433 U.S. 584 (1977).
} 
bodies through the behavioral potpourri of robbery murder do not necessarily make that task feasible.

\section{Weapons Policy}

We come now to two more straightforward applications of our data to the administration of the criminal law. The first concerns the use of weaponry in grading the seriousness of robbery, and the second concerns the desirability of reducing gun use in robbery. In each case, if reduction in death risk from robbery is a primary aim of the criminal law, special weapons policies seem justified.

Penal codes almost always distinguish between robberies involving weapons and those involving only personal force, and they frequently distinguish between firearms robbery and robbery involving other weapons. ${ }^{59}$ Our data confirm the validity of those classifications with respect to the risk of death. The death rate differences between armed and unarmed robbery suggest they should be regarded as two different crimes. Those between gun robbery and other forms of armed robbery are also substantial.

The extent to which grading decisions should be based on weapon dangerousness is another matter. Death risk from robbery is one, but not the only, variable on which penal policy decisions should be based. The abstract risk associated with different weapons should not be emphasized in sentencing policy to the point where disincentives to injure or kill lose significant force. This is one defect of long mandatory minimum sentences for firearm robbery. Further, there are other aspects of robbery policy, including the minimization of injury risks, that should inform decisions about sentencing that may not be closely related to weapon use. ${ }^{60}$

\section{Firearms Policy}

Sometimes clichés become so because they are true. The current data and preceding studies show the importance of a penal policy that attempts to minimize the use of firearms in violent crime. The role of the gun in determining the death toll from armed robbery is difficult to overstate. Many robberies, and thus many robbery killings, literally could not hap-

\footnotetext{
59 See, for example, Cal. Penal Code $\$ \S 12022,12022.5$ (West 1983); and Ill. Rev. Stat. (1983), ch. 38, §§ 33A-1, 33A-2, 33A-3. See also Franklin E. Zimring, Firearms and Federal Criminal Law, in 2 Working Papers of Federal Criminal Laws (1970), at 1031.

60 The relationship between weapon type and nonlethal injury is not obvious. Many forms of robbery with personal force appear to result in non-life-threatening injury more frequently than gun robbery does. See Cook, supra note 37, at 183.
} 
pen without a handgun. In many commercial settings, a handgun is nearly indispensable. For street robbery, guns are not necessary to the crime, but when used, they sharply escalate the risk of a lethal result. Obviously, any policy that reduces handgun involvement in violent crime will have an equivalent effect on the death rate. In this regard, the present data have all the novelty of a new study linking cigarettes to lung cancer and much of the force.

\section{APPENDIX}

\section{SUPPLEMENTARY TABLES}

TABLE A 1

Trends in Robiery Homicide and Motive-Undetermined HOMicide, Chicago, 1965-82

\begin{tabular}{lcc}
\hline \hline Year & $\begin{array}{c}\text { Number of Robbery } \\
\text { Homicides }\end{array}$ & $\begin{array}{c}\text { Number of Motive- } \\
\text { undetermined } \\
\text { Homicides }\end{array}$ \\
\hline 1965 & 31 & 9 \\
1966 & 50 & 25 \\
1967 & 63 & 29 \\
1968 & 62 & 31 \\
1969 & 97 & 59 \\
1970 & 146 & 106 \\
1971 & 132 & 76 \\
1972 & 129 & 57 \\
1973 & 166 & 121 \\
1974 & 210 & 162 \\
1975 & 175 & 137 \\
1976 & 147 & 121 \\
1977 & 114 & 183 \\
1978 & 139 & 139 \\
1979 & 160 & 168 \\
1980 & 161 & 197 \\
1981 & 156 & 190 \\
1982 & 95 & 143 \\
\hline
\end{tabular}

Source.-Chicago Police Department, Murder Analysis, 1965-82. Reports published annually except for 1965-69 figures, which are contained in a single report.

TABLE A2

Percentage Distribution of Robbery Killings by Victim-Offender Relationship (Possible Cases Included)

\begin{tabular}{lr}
\hline \hline Victim and offender acquainted & 20 \\
Victim and offender recognition & 4 \\
Stranger & 38 \\
Unknown & $\underline{38}$ \\
$\quad$ Total & $\underline{100}$ \\
$N$ & $\underline{133}$ \\
\hline
\end{tabular}


TABLE A3

Percentage of Robbery Killing Cases with Drug Indications

\begin{tabular}{lccr}
\hline & $\begin{array}{c}\text { Victim Is Drug } \\
\text { Dealer }\end{array}$ & $\begin{array}{c}\text { Offender Is Drug } \\
\text { Dealer }\end{array}$ & $\begin{array}{c}\text { Drugs at } \\
\text { Scene }\end{array}$ \\
\hline Yes & 16 & 13 & 26 \\
Probably yes & 5 & 13 & 6 \\
Probably no & 3 & 20 & 10 \\
No & 76 & 53 & 58 \\
$\quad$ Total & 100 & 99 & 31 \\
$N^{*}$ & 62 & 30 & 31 \\
\hline & * Includes in each column only those cases (out of a total of ninety-five) in which relevant information \\
is present.
\end{tabular}

TABLE A4

Distribution of Drug-Related and Nonstranger Robbery Killings by Location (Possible Cases Included)

\begin{tabular}{lcc}
\hline & Drug Related & Nonstranger \\
\hline Residential & 46 & 52 \\
Commercial & 4 & 10 \\
Street & 15 & 19 \\
Other & 35 & 19 \\
$\quad$ Total & 100 & 100 \\
$N$ & 26 & 31
\end{tabular}

TABLE A5

Percentage of Robbery Killings by Location Displaying Indications of Victim-Offender Social Distance (Possible Cases Included)

\begin{tabular}{lcccc}
\hline Location & $\begin{array}{c}\text { Victim and Offender } \\
\text { Not Strangers }\end{array}$ & $\begin{array}{c}\text { Victim and } \\
\text { Offender } \\
\text { of Same Race }\end{array}$ & $\begin{array}{c}\text { Victim and } \\
\text { Offender } \\
\text { within Ten Years }\end{array}$ & $\begin{array}{c}\text { Victim and } \\
\text { Offender } \\
\text { Both Males }\end{array}$ \\
\hline Residential & 62 & 79 & 35 & 69 \\
Commercial & 23 & 42 & 22 & 92 \\
Street & 32 & 79 & 37 & 92 \\
Other & 25 & 68 & 55 & 87 \\
All robbery & 38 & 71 & 39 & 83 \\
$\quad$ killings & 82 & 95 & 82 & 96 \\
$N$ & & & & \\
\hline
\end{tabular}


TABLE A6

Percentage Gun Use by Case Type and location

\begin{tabular}{lccc}
\hline & Robbery & $\begin{array}{c}\text { Robbery } \\
\text { with Injury }\end{array}$ & Death \\
\hline Residential & 32 & 18 & 29 \\
Commercial & 67 & 21 & 81 \\
Street & 39 & 13 & 67 \\
Other & 43 & 18 & 83 \\
\hline
\end{tabular}

